Table 1. Experimental (28) and theoretically estimated (Brownian dynamics) bimolecular rate constants $k_{2}\left(\mathrm{M}^{-1} \mathrm{~s}^{-1}\right)$ for the cytochrome $b_{5}$ self-exchange ET as a function of ionic strength $\mu$.

\begin{tabular}{llc}
\hline$\mu(\mathrm{M})$ & \multicolumn{2}{c}{$k_{2}\left(\mathrm{M}^{-1} \mathrm{~s}^{-1}\right)$} \\
\cline { 2 - 3 } & Experiment & Theory \\
\hline 0.1 & $2.6 \times 10^{3}$ & $1.0 \times 10^{3}$ \\
0.3 & $4.6 \times 10^{3}$ & $2.4 \times 10^{4}$ \\
0.6 & $1.6 \times 10^{4}$ & $7.6 \times 10^{4}$ \\
1.0 & $2.8 \times 10^{4}$ & $1.1 \times 10^{5}$ \\
1.5 & $4.5 \times 10^{4}$ & $1.7 \times 10^{5}$ \\
\hline
\end{tabular}

extended-Hückel approach to electronic coupling calculation is certainly dependent on its parameterization.

The existence of multiple tunneling regimes also provides insight into several recent (and otherwise puzzling) experimental and theoretical observations in biological ET reaction kinetics. Winkler, Gray, and co-workers found that ET across protein-protein interfaces in protein crystals mediated by three water molecules is nearly as rapid as unimolecular ET is over the same distance (7). Canters and co-workers showed that water dimers between covalently cross-linked azurin complexes could substantially enhance the intermolecular ET kinetics (15). Similarly, Klinman and coworkers investigated the copper-to-copper ET over about $7 \AA$ in the hydroxylating domain of peptidylglycine $\alpha$-amidylating monooxygenase and found an unusually large electronic coupling mediated, apparently, by water rather than by the protein or substrate (17). Using Pathways-level analysis, Onuchic and co-workers found that water molecules mediate the dominant ET coupling routes between cytochrome $\mathrm{c}_{2}$ and the photosynthetic reaction center (18). Cave and co-workers showed that water molecules between model $\mathrm{D}$ and A pairs substantially enhance intermolecular ET rates as well (19). All of these recent observations support our conclusion that a small number of structured water molecules interposed between the donor and the acceptor cofactors can substantially enhance ET rates.

The influence of aqueous tunneling pathways on interprotein ET kinetics has remained a key open issue in biological ET for some time. Single-exponential decay models fail to describe water-mediated ET reactions properly. The existence of multiple tunneling mediating regimes identified above is evinced by a body of recent experimental and theoretical observations. Most importantly, the structured water coupling regime may provide an important mechanism to facilitate ET reactions in the critical near-contact distance range relevant to biological ET kinetics. We hypothesize that water may be a particularly strong tunneling mediator when it occupies a sterically constrained space between redox cofactors with strong organizing forces that favor constructively interfering coupling pathways. It will be particularly interesting to use both theory and experiment to explore how the watermediated coupling between proteins varies with protein-protein shape complementarity, surface charge and polarity, and dynamical fluctuations of the proteins and of the organized water at the interface.

\section{References and Notes}

1. J. M. Berg, L. Stryer, J. L. Tymoczko, Biochemistry (Freeman, New York, ed. 5, 2002).

2. H. B. Gray, J. R. Winkler, Proc. Natl. Acad. Sci. U.S.A. 102, 3534 (2005)

3. Z. X. Liang et al., J. Am. Chem. Soc. 126, 2785 (2004).

4. A. Osyczka, C. C. Moser, F. Daldal, P. L. Dutton, Nature 427, 607 (2004).

5. H. B. Gray, J. R. Winkler, Q. Rev. Biophys. 36, 341 (2003).

6. R. E. Blankenship, Nat. Struct. Biol. 8, 94 (2001).

7. F. A. Tezcan, B. R. Crane, J. R. Winkler, H. B. Gray, Proc. Natl. Acad. Sci. U.S.A. 98, 5002 (2001).

8. G. McLendon, R. Hake, Chem. Rev. 92,481 (1992).

9. R. A. Marcus, N. Sutin, Biochim. Biophys. Acta 811 , 265 (1985).

10. S. S. Skourtis, I. A. Balabin, T. Kawatsu, D. N. Beratan, Proc. Natl. Acad. Sci. U.S.A. 102, 3552 (2005).

11. I. A. Balabin, J. N. Onuchic, Science 290, 114 (2000)

12. M. Jones, I. V. Kurnikov, D. N. Beratan, J. Phys. Chem. A 106, 2002 (2002)

13. C. C. Page, C. C. Moser, X. X. Chen, P. L. Dutton, Nature 402, 47 (1999).

14. M.-L. Tan, I. A. Balabin, J. N. Onuchic, Biophys. J. 86, 1813 (2004).

15. I. M. C. van Amsterdam et al., Nat. Struct. Biol. 9, 48 (2002).

16. R. N. Barnett, C. L. Cleveland, U. Landman, G. B. Schuster, Science 294, 567 (2001).

17. W. A. Francisco, G. Wille, A. J. Smith, D. J. Merkler, J. P. Klinman, J. Am. Chem. Soc. 126, 13168 (2004).

18. O. Miyashita, M. Y. Okamura, J. N. Onuchic, Proc. Natl. Acad. Sci. U.S.A. 102, 3558 (2005).

19. N. E. Miller, M. C. Wander, R. J. Cave, J. Phys. Chem A 103, 1084 (1999).

20. O. S. Wenger, B. S. Leigh, R. M. Villahermosa, H. B. Gray, J. R. Winkler, Science 307, 99 (2005)

21. A. Ponce, H. B. Gray, J. R. Winkler, J. Am. Chem. Soc. 122,8187 (2000).
22. I. Benjamin, D. Evans, A. Nitzan, J. Chem. Phys. 106, 6647 (1997).

23. M. D. Newton, J. Electroanal. Chem. 438, 3 (1997).

24. S. Larsson, J. Phys. Chem. 88, 1321 (1984).

25. J. R. R. Verlet, A. E. Bragg, A. Kammrath, O. Cheshnovsky, D. M. Neumark, Science 307, 93 (2004)

26. K. Onda et al., Science 308, 1154 (2005).

27. R. C. E. Durley, F. S. Mathews, Acta Crystallogr. D52, 65 (1996).

28. S. M. Andrew, K. A. Thomasson, S. H. Northrup, J. Am. Chem. Soc. 115, 5516 (1993).

29. S. H. Northrup, J. O. Boles, J. C. L. Reynolds, Science 241, 67 (1988).

30. P. Strittmatter et al., Proc. Natl. Acad. Sci. U.S.A. 71, 4565 (1974).

31. E. Hegesh, J. Hegesh, A. N. Kaftory, N. Engl. J. Med. 314, 757 (1986).

32. R. E. Utecht, D. M. Kurtz Jr., Biochim. Biophys. Acta 953, 164 (1988).

33. D. W. Dixon, X. Hong, S. E. Woehler, A. G. Mauk, B. P. Sishta, J. Am. Chem. Soc. 112, 1082 (1990).

34. W. L. Jorgensen, J. Chandrasekhar, J. D. Madura, R. W. Impey, M. L. Klein, J. Chem. Phys. 79, 926 (1983)

35. Details of system setup, electronic structure, molecular dynamics, and Brownian dynamics simulations are available on Science Online.

36. T. Kawatsu, T. Kakitani, T. Yamato, J. Phys. Chem. B 106, 5068 (2002).

37. P. Siddarth, R. A. Marcus, J. Phys. Chem. 97, 1308 (1993).

38. D. N. Beratan, J. N. Betts, J. N. Onuchic, Science 252, 1285 (1991).

39. H. Flyvbjerg, H. G. Petersen, J. Chem. Phys. 91, 461 (1989).

40. This work was supported by the NIH (GM-048043). We are grateful to H. B. Gray and J. R. Winkler for stimulating discussions. We thank T. Kawatsu for providing code for the $\mathrm{XH}$ calculations, I. V. Kurnikov for providing code for the Pathways-based and atomic packing density-based calculations, and M. A. Pasquinelli for assistance with the Brownian dynamics calculations.

Supporting Online Material

www.sciencemag.org/cgi/content/full/310/5752/1311/ DC1

SOM Text

Figs. S1 to S6

References

2 August 2005; accepted 20 October 2005

10.1126/science. 1118316

\title{
Stable Carbon Cycle-Climate Relationship During the Late Pleistocene
}

\section{Urs Siegenthaler, ${ }^{1}$ Thomas F. Stocker, ${ }^{1 *}$ Eric Monnin, ${ }^{1}$ Dieter Lüthi, ${ }^{1}$ Jakob Schwander, ${ }^{1}$ Bernhard Stauffer, ${ }^{1}$ Dominique Raynaud, ${ }^{2}$ Jean-Marc Barnola, ${ }^{2}$ Hubertus Fischer, ${ }^{3}$ Valérie Masson-Delmotte, ${ }^{4}$ Jean Jouzel ${ }^{4}$}

\begin{abstract}
A record of atmospheric carbon dioxide $\left(\mathrm{CO}_{2}\right)$ concentrations measured on the EPICA (European Project for Ice Coring in Antarctica) Dome Concordia ice core extends the Vostok $\mathrm{CO}_{2}$ record back to 650,000 years before the present (yr B.P.). Before 430,000 yr B.P., partial pressure of atmospheric $\mathrm{CO}_{2}$ lies within the range of 260 and 180 parts per million by volume. This range is almost $30 \%$ smaller than that of the last four glacial cycles; however, the apparent sensitivity between deuterium and $\mathrm{CO}_{2}$ remains stable throughout the six glacial cycles, suggesting that the relationship between $\mathrm{CO}_{2}$ and Antarctic climate remained rather constant over this interval.
\end{abstract}

The European Project for Ice Coring in Antarctica (EPICA) recovered two deep ice cores from East Antarctica. One of the cores, located at Dome Concordia (Dome C) $\left(75^{\circ} 06^{\prime} \mathrm{S}\right.$, $123^{\circ} 21^{\prime} \mathrm{E}$, altitude of $3233 \mathrm{~m}$ above sea level, and mean annual accumulation rate of 25.0 


\section{R E P O R T S}

Fig. 1. Dome $\mathrm{CCO}_{2}$ Bern data (black solid circles) are the mean of four to six samples, including the data from 31 depth intervals over termination $\mathrm{V}$ of (1); error bars denote $1 \sigma$ of the mean. Red solid circles are test measurements with the use of the sublimation extraction technique. Dome $\mathrm{C} \mathrm{CO}_{2}$ Grenoble data are shown as black open circles. Dome $\mathrm{C} \mathrm{CO}_{2}$ measurements are connected with a blue line, and the highresolution deuterium record is given as a black line (18). Benthic $\delta^{18} \mathrm{O}$ stack and benthic $\delta^{18} \mathrm{O}$ record from ODP site 980 are shown as a dark gray line (19) and a light gray line (19-22), respectively. The EDC2 time scale for Dome C is the same as in (1) (the depths at the top of the figure are only valid for the $\mathrm{CO}_{2}$ record). Glacial terminations are given in roman numerals; marine isotope stages are given in arabic numerals according to (17).

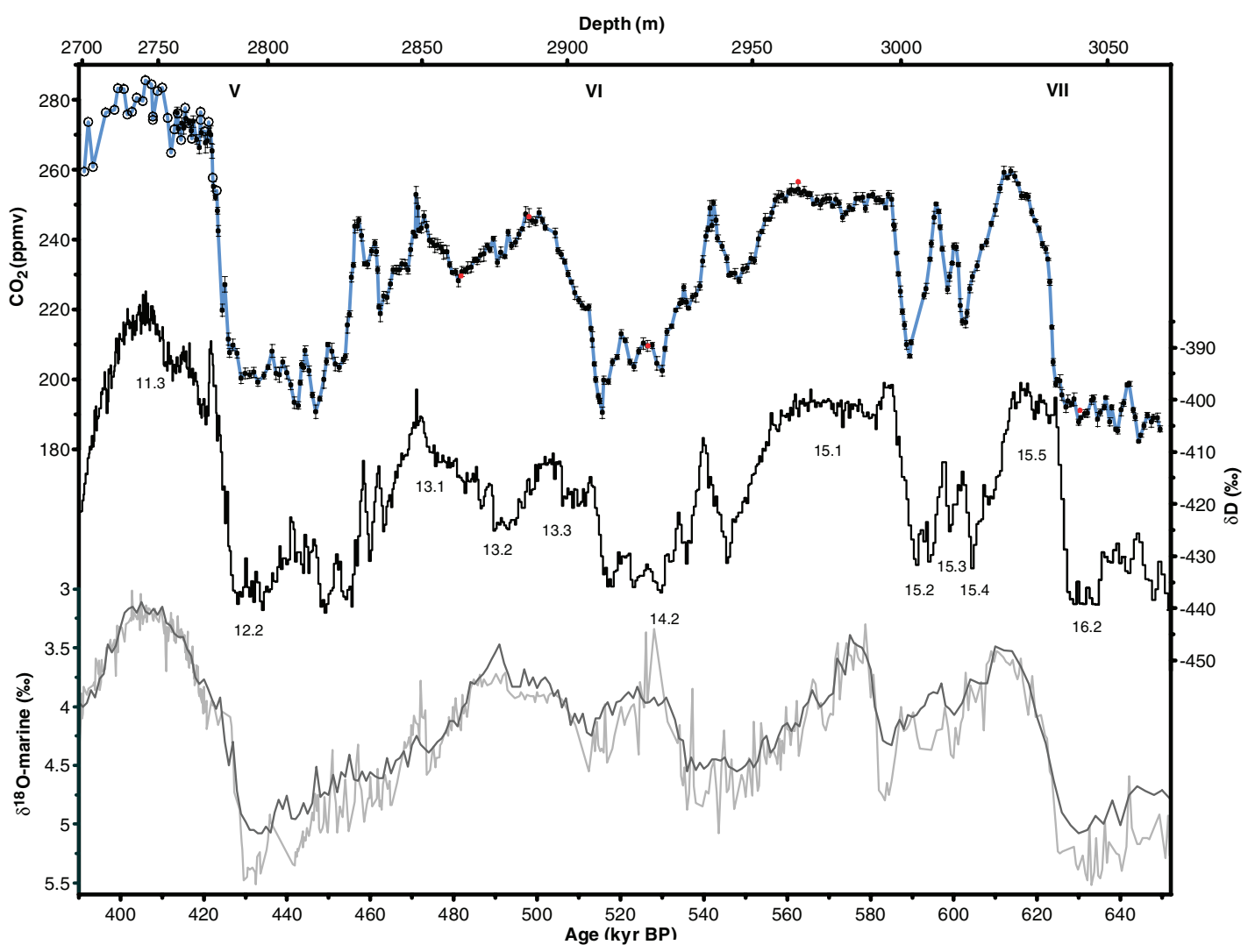

$\mathrm{kg} \mathrm{m}^{-2}$ year $^{-1}$ ), is the only ice core covering at least eight glacial cycles (1), four cycles longer than previously available from ice cores. This has allowed us to reconstruct the record of the concentration of atmospheric $\mathrm{CO}_{2}$ much further back in time than was possible before. Here, we report results from the interval between 390 and 650 kyr B.P. (kyr B.P. is thousand years before the present, i.e., before A.D. 1950).

Analyzing the air extracted from ice cores is the only way to directly determine atmospheric greenhouse gas concentrations for times before routine atmospheric measurements were begun. Antarctic ice cores are very suitable for $\mathrm{CO}_{2}$ measurements because of their low temperatures and low concentrations of impurities, which minimize the risk of artifacts. Data from different Antarctic ice cores (2-13) and drilled at sites with different temperatures, accumulation rates, and impurity concentrations [except

${ }^{1}$ Climate and Environmental Physics, Physics Institute, University of Bern, Sidlerstrasse 5, CH-3012 Bern, Switzerland. 'Laboratoire de Glaciologie et de Géophysique de l'Environnement (CNRS), 54 Rue Molières, 38402 St. Martin d'Hères Cedex, France. ${ }^{3}$ Alfred Wegener Institute for Polar and Marine Research (AWI), Columbusstrasse, D-27568 Bremerhaven, Germany. ${ }^{4}$ Institut Pierre Simon Laplace/ Laboratoire des Sciences du Climat et de l'Environnement, CEA-CNRS 1572, CE Saclay, Orme des Merisiers, 91191 Gif-sur-Yvette, France.

*To whom correspondence should be addressed. E-mail: stocker@climate.unibe.ch cores with summer melting (14) and where elevated $\mathrm{CO}_{2}$ values by up to 20 parts per million by volume (ppmv) are found] demonstrate that Antarctic ice cores are reliable recorders of atmospheric $\mathrm{CO}_{2}$.

The concentrations of atmospheric $\mathrm{CO}_{2}$ during the past four glacial cycles measured in the Vostok ice core vary between glacial and interglacial values of $180 \mathrm{ppmv}$ and 280 to 300 ppmv, respectively (7). Including the data from Petit et al. (7), Fischer et al. (5) and Kawamura et al. (10), the lowest and highest values measured during a glacial cycle are on average $182 \pm 4$ ppmv ( \pm 1 standard deviation) and $296 \pm 7$ ppmv, respectively. This stable range of natural $\mathrm{CO}_{2}$ variations on glacialinterglacial time scales led to the suggestion that feedbacks in the climate influence on the global carbon cycle maintain the rather narrow range observed (15).

The Dome $\mathrm{C} \mathrm{CO}_{2}$ record [mean sampling resolution of 731 years; details about the methods and the sampling are given in (16)] is plotted in Fig. 1, together with the $\delta \mathrm{D}$ record (Antarctic temperature proxy) of Dome C (18) [both records are shown on the EDC2 time scale (1)], a stack of benthic $\delta^{18} \mathrm{O}$ records from globally distributed sites (19), and a high-resolution benthic $\delta^{18} \mathrm{O}$ record from Ocean Drilling Project (ODP) site $980\left(55^{\circ} 29^{\prime} \mathrm{N}, 14^{\circ} 42^{\prime} \mathrm{W}\right)(19-22)$. There is an excellent overall correlation between $\delta \mathrm{D}$ and benthic $\delta^{18} \mathrm{O}$, a proxy of global ice volume (19).
First, we discuss the main features of the $\mathrm{CO}_{2}$ record from Dome $\mathrm{C}$ from 650 to 390 kyr B.P. Our measurements begin at $650 \mathrm{kyr}$ B.P., close to the lowest value for the entire record of $182 \mathrm{ppmv}$ at $644 \mathrm{kyr}$ B.P.. At marine isotope stage (MIS) 16, the $\mathrm{CO}_{2}$ concentration is about $190 \mathrm{ppmv}$ before the onset of termination VII. The entire transition between glacial and interglacial $\delta \mathrm{D}$ values occurred rapidly, within 3 kyear (ky) with the EDC2 dating. As expected from firnification processes, the corresponding $\mathrm{CO}_{2}$ increase occurred deeper in the ice core, so there is no indication for an ice flow disturbance at this depth of about $3040 \mathrm{~m}$, as has been observed at certain depths in the lowest $10 \%$ of some ice cores $(7,23)$. After emerging slowly out of the baseline band, the $\mathrm{CO}_{2}$ increase can be divided in two intervals. The first increase of 35 ppmv up to a $\mathrm{CO}_{2}$ concentration of 235 ppmv takes less than 2 $\mathrm{ky}$, whereas the second increase of another 20 ppmv takes about $5 \mathrm{ky}$. Although the $\mathrm{CO}_{2}$ trend at the beginning of the interglacial MIS 15.5 does not show an early $\mathrm{CO}_{2}$ peak as during the past four interglacials, this second $\mathrm{CO}_{2}$ increase is very similar in magnitude (20 ppmv) and duration (5 ky) to the Holocene one, although evolving with generally lower $\mathrm{CO}_{2}$ values by about 25 ppmv. Therefore, the Holocene increase during the last 8 kyear is not an anomalous trend in comparison to other interglacials as postulated recently (24); instead it is a likely response of the carbon cycle 


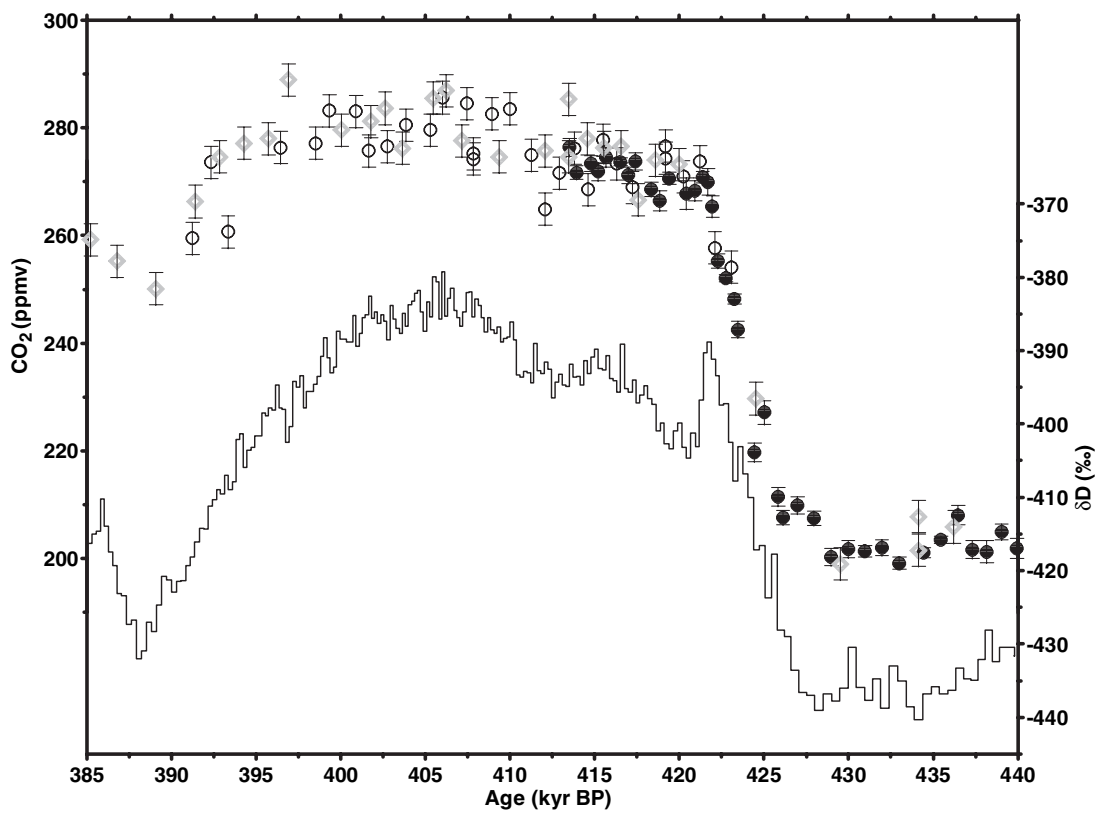

Fig. 2. $\mathrm{CO}_{2}$ results of entire MIS 11, including end of MIS 12. Dome $\mathrm{CCO}_{2}$ Bern data (solid circles) from EPICA community members (1) and this work; error bars, $1 \sigma$ of the mean. Dome $\mathrm{C} \mathrm{CO}_{2}$ Grenoble data are indicated by open circles; error bars, accuracy of $2 \sigma=3$ ppmv. High-resolution deuterium record is shown as a black line (18). Vostok $\mathrm{CO}_{2}$ Grenoble data are indicated by gray open diamonds; error bars, accuracy of $2 \sigma=3$ ppmv on the corrected time scale (28).

to large changes in biomass (25). At the end of MIS 15.5, $\mathrm{CO}_{2}$ attains its local maximum of about 260 ppmv, which is the highest concentration in the record before MIS 11 but substantially lower than the interglacial concentrations measured during the last four glacial cycles. At MIS 15.4 and MIS 15.2, the deuterium record indicates near-glacial conditions, only interrupted by two peaks at MIS 15.3. During the time interval of MIS 15.4 to $15.2, \mathrm{CO}_{2}$ shows rather large variations, with values between 207 ppmv and 250 ppmv and with two peaks during MIS 15.3 that are very similar to the deuterium peaks. The lowest values are close to glacial $\mathrm{CO}_{2}$ concentrations, which raise the question of whether MIS 15 was a single continuous interglacial or multiple ones.

The increases of $\mathrm{CO}_{2}$ and $\delta \mathrm{D}$ into MIS 15.1 are very uniform and take 4 to $5 \mathrm{ky}$ for each component. An unexpected feature is the very stable and long-lasting MIS 15.1. In contrast to the increasing global ice volume suggested by the benthic records of marine sediments (Fig. 1) (19), all indicators from Dome $\mathrm{C}$ exhibit almost constant values during MIS 15.1. This is observed in the records of deuterium (1), of $\mathrm{CH}_{4}$ (26), and of aerosols (27) of the Dome C ice core but is most pronounced in our $\mathrm{CO}_{2}$ results. We find a stable $251.5 \pm 1.9$ ppmv ( \pm 1 standard deviation) $\mathrm{CO}_{2}$ concentration from $585 \mathrm{kyr}$ B.P. to $557 \mathrm{kyr}$ B.P. on the EDC2 time scale, which is unprecedented in any other time interval covered by previous $\mathrm{CO}_{2}$ measurements on ice cores. This result suggests that the global carbon cycle operated in an exceptionally stable mode for many millennia. The current estimate for the duration of MIS 15.1, on the basis of the EDC2 time scale, is 28,000 years. Accordingly, this interval is a prime target for developing a better understanding of the influence of orbital geometry on climate and the global carbon cycle. However, we cannot, at this stage, exclude the possibility that at least part of the exceptionally long duration of stable conditions could be due to an exceptionally low thinning rate of the corresponding ice layer.

The decrease in $\delta \mathrm{D}$ from the end of MIS 15.1 to the start of MIS 14.2 is interrupted by a double peak, the older of which is most pronounced with a corresponding peak in the $\mathrm{CO}_{2}$ record and with elevated values by between $\mathrm{CO}_{2}$ and deuterium for this event is dicussed later in the text. The deuterium increase to the maximum value of MIS 13.3 ("termination" VI) evolves in two steps, with a rather stable concentration in between and a difference between glacial and interglacial values that is smaller in comparison to any other termination during the past $650 \mathrm{ky}$. The $\mathrm{CO}_{2}$ increase can be divided again into two intervals, as for termination VII. The first increase of $30 \mathrm{ppmv}$ takes $3 \mathrm{ky}$, whereas the duration for the second increase of $20 \mathrm{ppmv}$ is more than $8 \mathrm{ky}$. During MIS 13, $\mathrm{CO}_{2}$ values are in the range of about 230 to 250 ppmv, with a minimum at $481 \mathrm{kyr}$ B.P. This minimum lags the deuterium minimum by about $10 \mathrm{ky}$. The decrease to MIS 12.2 is more than 20 ppmv. The phase relationship interrupted by another prominent set of deuterium and $\mathrm{CO}_{2}$ double peaks. During MIS 12.2 (and also MIS 16.2) we find pronounced millennial $\mathrm{CO}_{2}$ fluctuations of 10 to 20 ppmv. They are comparable in duration and amplitude to the distinct $\mathrm{CO}_{2}$ peaks observed during the past four Antarctic warm events (A1 to A4) during the last glacial $(4,8)$.

A detailed comparison with Vostok data (28) during MIS 11, an interglacial period that occurred some 400,000 years ago and lasted for about 30,000 years, is shown in Fig. 2 in order to examine the consistency of $\mathrm{CO}_{2}$ values measured in this deep ice. Both records agree within the error limits and show interglacial $\mathrm{CO}_{2}$ concentrations in MIS 11 similar to those found in the Holocene. Accordingly, we are confident that the Dome $\mathrm{C}$ data in the pre-Vostok era reflect true atmospheric $\mathrm{CO}_{2}$ concentrations.

The coupling of $\mathrm{CO}_{2}$ and $\delta \mathrm{D}$ is strong. The overall correlation between $\mathrm{CO}_{2}$ data and Antarctic temperature during the time period of 390 to $650 \mathrm{kyr}$ B.P. is $r^{2}=0.71$. Taking into account only the period 430 to 650 kyr B.P., where amplitudes of deuterium and $\mathrm{CO}_{2}$ are smaller, the correlation is $r^{2}=$ 0.57 . Corrections for changes in the temperature and $\delta \mathrm{D}$ of the water vapor source, which also affect $\delta \mathrm{D}$ of the ice, have not been made yet. The strong coupling of $\mathrm{CO}_{2}$ to Antarctic temperature confirms earlier observations for the last glacial termination (9) and the past four glacial cycles (7) and supports the hypothesis that the Southern Ocean played an important role in causing $\mathrm{CO}_{2}$ variations.

$\delta \mathrm{D}$ as a function of $\mathrm{CO}_{2}$ from the Vostok (MIS 1 to MIS 11) and Dome $\mathrm{C}$ ice cores [MIS 12 to 16, Holocene (11), and termination I (9)] is shown in Fig. 3. The offset in the deuterium values of Dome $\mathrm{C}$ and Vostok is due to the different distances to the open ocean, elevations, and surface temperatures of the two sites (29). It is remarkable that the slope of the three records is essentially the same. This suggests that the coupling of Antarctic temperature and $\mathrm{CO}_{2}$ did not change substantially during the last $650 \mathrm{ky}$.

Another important parameter elucidating the coupling of atmospheric $\mathrm{CO}_{2}$ and Antarctic temperature is their relative phasing. Because of the enclosure process of air in ice, the phase relationship of $\mathrm{CO}_{2}$ and $\delta \mathrm{D}$ is associated with uncertainties. Because the enclosed air is younger than the surrounding ice (30), $\mathrm{CO}_{2}$ is plotted on a gas age chronology, whereas deuterium is plotted on an ice age chronology. For Dome $\mathrm{C}$ and the period under investigation, the gas age/ ice age difference ( $\Delta$ age) is in the range of 1.9 to $5.5 \mathrm{ky}$ (fig. S1). The estimated uncertainty of $\Delta$ age in the upper $800 \mathrm{~m}$ of 


\section{R E P O R T S}

the Dome C ice core is about $10 \%(31)$, neglecting uncertainties in the thinning rate. Deviations from the modeled thinning would introduce systematic errors in $\Delta$ age.

By shifting the time scales of the entire $\mathrm{CO}_{2}$ and deuterium records between 390 and 650 kyr B.P. relative to each other, we obtained the best correlation for a lag of $\mathrm{CO}_{2}$ of 1900 years. This lag is significant considering the uncertainties of $\Delta$ age. Over the glacial terminations $\mathrm{V}$ to VII, the highest correlation of $\mathrm{CO}_{2}$ and deuterium, with use of a 20-ky window for each termination, yields a lag of $\mathrm{CO}_{2}$ to deuterium of 800 ,
1600, and 2800 years, respectively. This value is consistent with estimates based on data from the past four glacial cycles. Fischer et al. (5) concluded that $\mathrm{CO}_{2}$ concentrations lagged Antarctic warmings by $600 \pm 400$ years during the past three transitions. Monnin et al. (9) found a lag of 800 \pm 600 years for termination I, and Caillon et al. (32), with use of the isotopic composition of argon in air bubbles instead of deuterium, calculated a value of $800 \pm 200$ years for termination III. Overall, the estimated lags over the entire Dome $\mathrm{C}$ record between 390 and $650 \mathrm{kyr}$ B.P. and over the three ter-

Fig. 3. Correlation between $\delta D$, a proxy for Antarctic temperature, and $\mathrm{CO}_{2}$ for three data sets. The new data from Dome C cover the beginning of MIS 12 to MIS 16 (black solid circles; black line is the linear fit $\delta D=0.44 \%$ o $\mathrm{ppmv}^{-1} \times \mathrm{CO}_{2}-$ $517.75 \%, r^{2}=0.57$ ), and the period from MIS 1 to MIS 11 is covered by data from the Vostok ice core [gray solid circles (7); gray line is linear fit, $\delta \mathrm{D}=0.50 \%$ o $\mathrm{ppmv}^{-1} \times$ $\mathrm{CO}_{2}-575.86 \%$ o, $r^{2}=$ $0.70]$ and Dome $C$ Holocene and termination I [black open circles $(9,11)$; black dashed line is the linear fit, $\delta D=0.50 \%$ $\mathrm{ppmv}^{-1} \times \mathrm{CO}_{2}-$ $529.87 \%$, $\left.r^{2}=0.84\right]$.

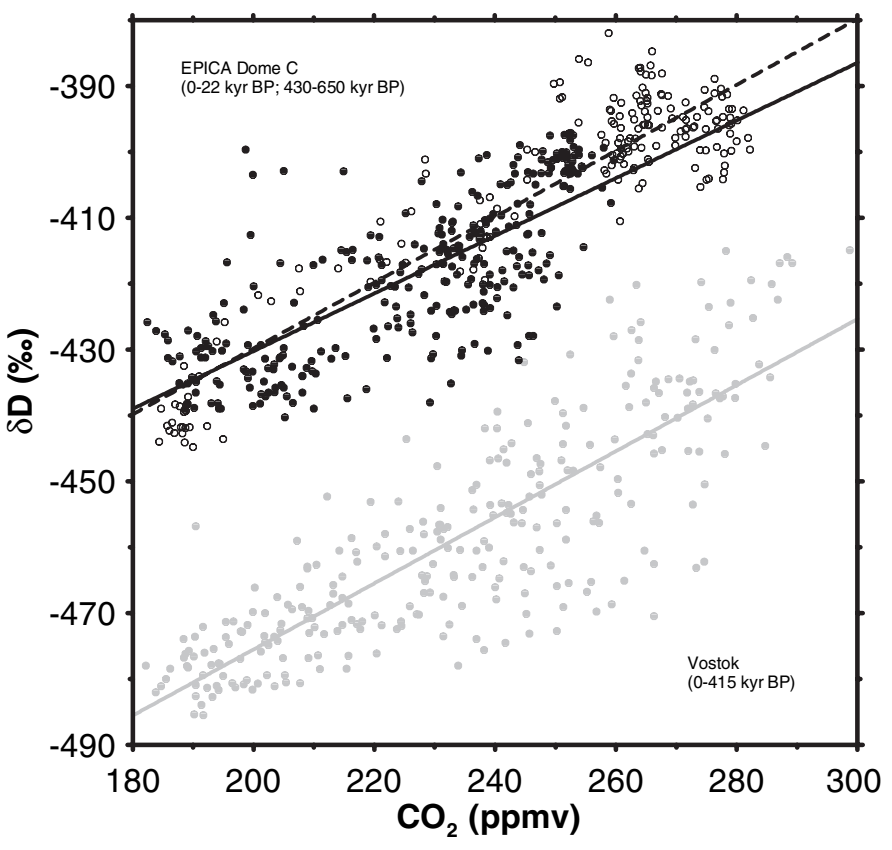

The offset in the $\delta D$ values from these two cores is due to the different distances to the open ocean, elevations, and surface temperatures of the two sites (29). minations in this time period are small compared with glacial-interglacial time scales and do not cast doubt on the strong coupling of $\mathrm{CO}_{2}$ and temperature or on the importance of $\mathrm{CO}_{2}$ as a key amplification factor of the large observed temperature variations of glacial cycles.

An apparent exception of the lag of $\mathrm{CO}_{2}$ to deuterium observed over most of the record occurs around 534 to 548 kyr B.P., where $\mathrm{CO}_{2}$ seems to lead $\delta \mathrm{D}$ by about $2000 \pm$ 500 year. We cannot conclude with certainty whether the observed lead of $\mathrm{CO}_{2}$ at this time is real or an artefact in the EDC2 time scale. To make the $\mathrm{CO}_{2}$ and the $\delta \mathrm{D}$ peaks simultaneous, we would need to increase the modeled depth offset of the gas record and the ice record ( $\Delta$ depth) from $4.3 \mathrm{~m}$ to $7 \mathrm{~m}$ (fig. S2). This can be achieved by a reduced thinning rate, an increased accumulation rate, a decreased temperature, or a combination of them. However, because accumulation and temperature are strongly positively correlated at present (33), the required change in accumulation or temperature, or a change of both, is rather unlikely. An anomalously low thinning rate is therefore the more likely way to produce such an artefact in the EDC2 time scale.

A composite $\mathrm{CO}_{2}$ record over six and a half ice age cycles back to $650,000 \mathrm{yr}$ B.P. is shown in Fig. 4, created from a combination of records from the Dome C, Taylor Dome, and Vostok ice cores. This record shows the differences in amplitudes of $\mathrm{CO}_{2}$ and deuterium before and after $430 \mathrm{kyr}$ B.P. and demonstrates, within the resolution of our measurements, that the atmospheric concentration of $\mathrm{CO}_{2}$ did not exceed 300 ppmv for the last 650,000 years before the preindustrial era.
Fig. 4. A composite $\mathrm{CO}_{2}$ record over six and a half ice age cycles, back to 650,000 years B.P. The record results from the combination of $\mathrm{CO}_{2}$ data from three Antarctic ice cores: Dome C (black), 0 to $22 \mathrm{kyr}$ B.P. $(9,11)$ and 390 to $650 \mathrm{kyr}$ B.P. [this work including data from 31 depth intervals over termination $\mathrm{V}$ of (1)]; Vostok (blue), 0 to 420 kyr B.P. $(5,7)$, and Taylor Dome (light green), 20 to 62 yr B.P. (8). Black line indicates $\delta D$ from Dome C, 0 to 400 kyr B.P. (1) and 400 to 650 kyr B.P. (18). Blue line indicates $\delta \mathrm{D}$ from Vostok, 0 to 420 kyr B.P. (7).

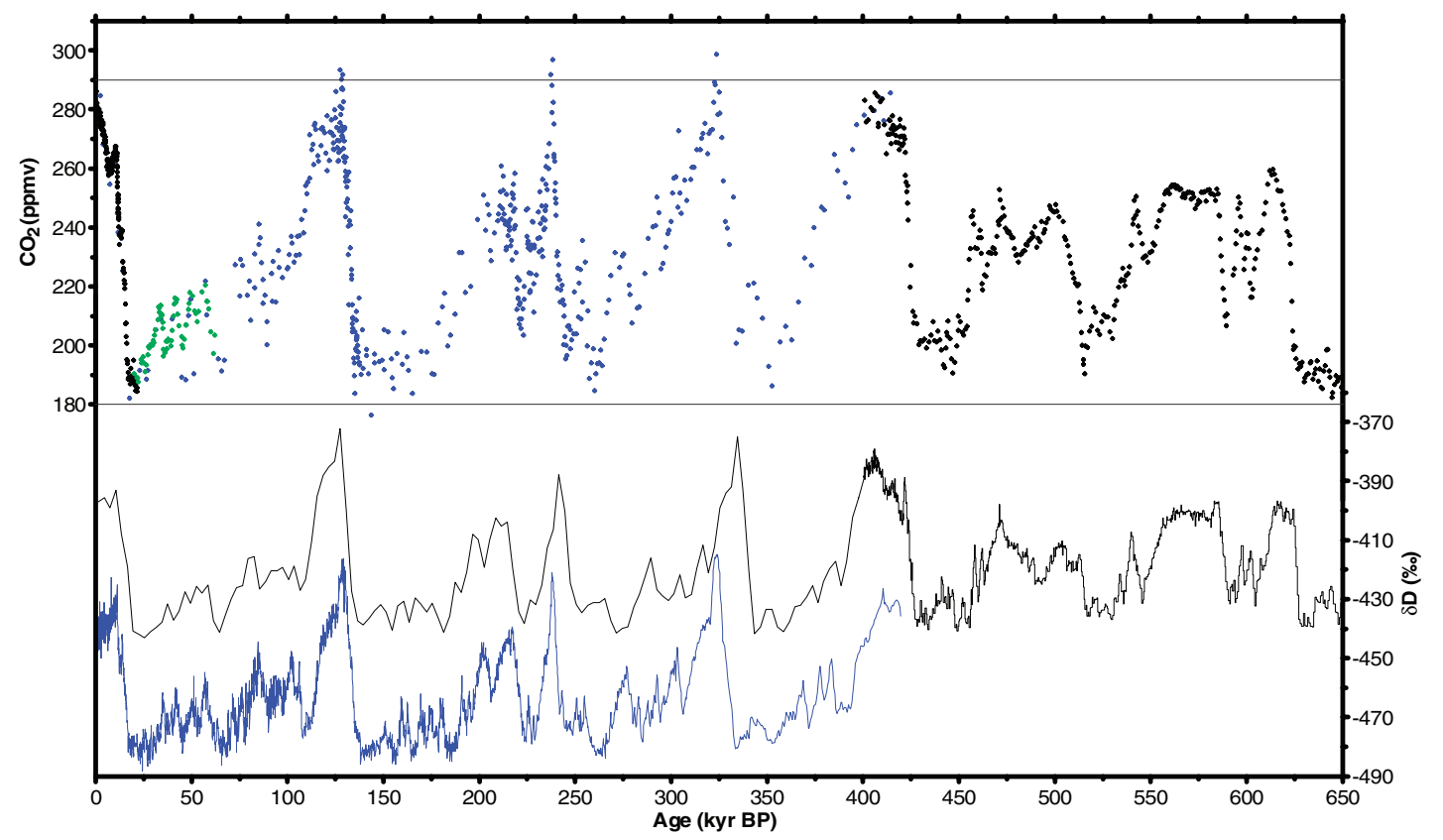


The $\mathrm{CO}_{2}$ record from the EPICA Dome $\mathrm{C}$ ice core reveals that atmospheric $\mathrm{CO}_{2}$ variations during glacial-interglacial cycles had a notably different character before and after $430 \mathrm{kyr}$ B.P. Before MIS 11, the amplitude of temperature was lower, and the duration of the warm phases has been much longer since then. In spite of these differences, the significant covariation of $\delta \mathrm{D}$ and $\mathrm{CO}_{2}$ is valid in both periods. Before MIS 11, $\mathrm{CO}_{2}$ concentrations did not exceed 260 ppmv. This is substantially lower than the maxima of the last four glacial cycles. The lags of $\mathrm{CO}_{2}$ with respect to the Antarctic temperature over glacial terminations $\mathrm{V}$ to VII are 800,1600 , and 2800 years, respectively, which are consistent with earlier observations during the last four glacial cycles.

Our measurements have revealed an unexpected stable climate phase (MIS 15.1) during which the atmospheric $\mathrm{CO}_{2}$ concentration was $251.5 \pm 1.9 \mathrm{ppmv}$ for many millennia $(28,000$ years, based on the EDC2 time scale), although the duration of MIS 15.1 is uncertain because of possible inaccuracies in the Dome C EDC2 time scale between MIS 12 and 15. However, the roughly 30,000-year duration of MIS 11 (and possibly MIS 15.1) demonstrates that long interglacials with stable conditions are not exceptional. Short interglacials such as the past three therefore are not the rule and hence cannot serve as analogs of the Holo- cene, as postulated recently (24). Examining $\delta \mathrm{D}$ as a function of $\mathrm{CO}_{2}$, we observe that the slope during the two new glacial cycles compared to the last four cycles is essentially the same. Therefore, the coupling of Antarctic temperature and $\mathrm{CO}_{2}$ did not change significantly during the last 650 kyear, indicating rather stable coupling between climate and the carbon cycle during the late Pleistocene.

\section{References and Notes}

1. L. Augustin et al., (EPICA community members), Nature 429, 623 (2004).

2. J.-M. Barnola, D. Raynaud, Y. S. Korotkevich, C. Lorius, Nature 329, 408 (1987).

3. D. M. Etheridge et al., J. Geophys. Res. 101, 4115 (1996).

4. B. Stauffer et al., Nature 392, 59 (1998).

5. H. Fischer, M. Wahlen, J. Smith, D. Mastroianni, B. Deck, Science 283, 1712 (1999).

6. A. Indermühle et al., Nature 398, 121 (1999).

7. J. R. Petit et al., Nature 399, 429 (1999).

8. A. Indermühle, E. Monnin, B. Stauffer, T. F. Stocker, M. Wahlen, Geophys. Res. Lett. 27, 735 (2000).

9. E. Monnin et al., Science 291, 112 (2001).

10. K. Kawamura et al., Tellus 55B, 126 (2003).

11. E. Monnin et al., Earth Planet. Sci. Lett. 224, 45 (2004).

12. U. Siegenthaler et al., Tellus 57B, 51 (2005).

13. J. Flückiger et al., Global Biogeochem. Cycles 16, 1010 (2002)

14. J. Ahn et al., J. Geophys. Res. 109, 10.1029/ 2003JD004415 (2004).

15. P. Falkowski et al., Science 290, 291 (2000).

16. Supplementary information concerning methods or assumptions is available on Science Online.

17. F. C. Bassinot et al., Earth Planet. Sci. Lett. 126, 91 (1994).

18. J. Jouzel et al., in preparation.

19. L. E. Lisiecki, M. E. Raymo, Paleoceanography 20, 10.1029/2004PA001071 (2005).

20. D. W. Oppo, J. F. McManus, J. L. Cullen, Science 279, 1335 (1998).

21. J. F. McManus, D. W. Oppo, J. L. Cullen, Science 283, 971 (1999).

22. B. P. Flower et al., Paleoceanography 15, 388 (2000)

23. A. Landais et al., J. Geophys. Res. 109, 10.1029/ 2003JD004193 (2004)

24. W. F. Ruddiman, Clim. Change 61, 261 (2003).

25. F. Joos, S. Gerber, I. C. Prentice, B. L. Otto-Bliesner, P. J. Valdes, Global Biogeochem. Cycles 18, 10.1029/ 2003GB002156 (2004).

26. R. Spahni et al., Science 310, 1317 (2005).

27. E. W. Wolff et al, in preparation.

28. D. Raynaud et al., Nature 436, 39 (2005)

29. V. Masson et al., Quaternary Res. 54, 348 (2000)

30. J. Schwander, B. Stauffer, Nature 311, 45 (1984).

31. J. Schwander et al., Geophys. Res. Lett. 28, 4243 (2001).

32. N. Caillon et al., Science 299, 1728 (2003).

33. J. Jouzel et al., Nature 329, 403 (1987).

34. We thank K. Kawamura and G. Teste for assisting with the $\mathrm{CO}_{2}$ measurements, L. Lisiecki and M. Raymo for access to the data of (19), and R. Spahni and F. Parrenin for fruitful discussions. This work is a contribution to the EPICA, a joint European Science Foundation/ European Commission (EC) scientific program funded by the $\mathrm{EC}$ and by national contributions from Belgium, Denmark, France, Germany, Italy, Netherlands, Norway, Sweden, Switzerland, and United Kingdom. We acknowledge long-term financial support by the Swiss National Science Foundation, the University of Bern, the Swiss Federal Office of Energy, and EC Project EPICA-MIS. This is EPICA publication no. 133.

Supporting Online Material

www.sciencemag.org/cgi/content/full/310/5752/1313/ DC1

Materials and Methods

Figs. S1 and S2

References

13 September 2005; accepted 1 November 2005 $10.1126 /$ science. 1120130

sphere in the past. The European Project for Ice Coring in Antarctica (EPICA) Dome Concordia (Dome C) ice core $\left(75^{\circ} 06^{\prime} \mathrm{S}\right.$, $123^{\circ} 21^{\prime} \mathrm{E}, 3233 \mathrm{~m}$ above sea level) provides an ice core archive much longer, spanning eight climatic cycles over the past 740 thousand years (ky) (3). It demonstrates that the oldest four interglacials were cooler but lasted longer than the younger interglacials. Such findings raise the question whether the greenhouse gases $\mathrm{CH}_{4}$ and $\mathrm{N}_{2} \mathrm{O}$ behaved differently before MIS 11 . Here, we present $\mathrm{CH}_{4}$ and $\mathrm{N}_{2} \mathrm{O}$ records derived from the EPICA Dome $\mathrm{C}$ ice cores reaching back to $650 \mathrm{kyr}$ B.P.

\begin{abstract}
The European Project for Ice Coring in Antarctica Dome $\mathrm{C}$ ice core enables us to extend existing records of atmospheric methane $\left(\mathrm{CH}_{4}\right)$ and nitrous oxide $\left(\mathrm{N}_{2} \mathrm{O}\right)$ back to 650,000 years before the present. A combined record of $\mathrm{CH}_{4}$ measured along the Dome $\mathrm{C}$ and the Vostok ice cores demonstrates, within the resolution of our measurements, that preindustrial concentrations over Antarctica have not exceeded $773 \pm 15$ ppbv (parts per billion by volume) during the past 650,000 years. Before 420,000 years ago, when interglacials were cooler, maximum $\mathrm{CH}_{4}$ concentrations were only about 600 ppbv, similar to lower Holocene values. In contrast, the $\mathrm{N}_{2} \mathrm{O}$ record shows maximum concentrations of $278 \pm 7$ ppbv, slightly higher than early Holocene values.
\end{abstract}

Earth's climate during the late Pleistocene was characterized by ice age cycles with relatively short warm periods (interglacials) and longer cold periods (glacials) (1). The Vostok ice core provided an archive of climate and atmospheric composition over the past four climatic cycles back to marine isotope stage (MIS) 11, about 420 thousand years before the present (420 kyr B.P.) (2). That record demonstrated the high correlation of temperature changes with greenhouse gas concentration changes in the atmo-
${ }^{1}$ Climate and Environmental Physics, Physics Institute University of Bern, Sidlerstrasse 5, CH-3012 Bern, Switzerland. ${ }^{2}$ Laboratoire de Glaciologie et Géophysique de l'Environnement (LGGE, CNRS-UJF), CNRS, 54 Rue Molières, 38402 St. Martin d'Hères, Grenoble, France. ${ }^{3}$ Institut Pierre Simon Laplace/Laboratoire des Sciences du Climat et de l'Environnement, CEA-CNRS 1572, CE Saclay, Orme des Merisiers, 91191 Gif-surYvette, France.

*To whom correspondence should be addressed: stocker@climate.unibe.ch

$\dagger$ Present address: Scripps Institution of Oceanography, University of California, San Diego, 9500 Gilman Drive, La Jolla, CA 92093-0244, USA.

$\$$ Present address: Institute of Arctic and Alpine Research, University of Colorado at Boulder, 450 UCB Boulder, Colorado 80309-0450, USA. 